\title{
Milestones, Touchstones and Just Plain Stones
}

BERNARD P. RICCA

St. John Fisher College (USA)

I spent a wonderful time this past summer in the western part of Ireland. One distinguishing feature of that land is the ubiquitous stone wall. These walls have been built from the stones percolating to the surface of the stony and rocky land; the percolation began thousands of years ago and continues to this day. I learned little about these walls from the residents inside those walls; those who were old enough to remember their construction spoke a language that was largely impenetrable to me; it may have been English, or it may have been Gaelic, or almost anything else, so different was the accent from my own. And while I have many pictures with stones in them, I have no real understanding of the stones or the people of those stones. So perhaps stones were on my mind as I sat down to work on this editorial.

As I start to write this, it is still 2013, which is 20 years after the publishing of Bill Doll's A Post-modern Perspective on Curriculum, which, as much as any other event, ushered complexity as a field of study into education. Furthermore, it was 10 years ago that the first Complexity Science and Educational Research conference was held and, as an outgrowth of that conference, that Complicity was begun. 20 years and 10 years seem like important milestones in the complexity-studies-in-education world.

But what does it mean to pass a milestone? I did not need to consult my Oxford English Dictionary to figure that "mile stone" was a marker of sorts along a path. (However, as I have learned to be most skeptical of the things that seem commonsensical to me, I did check: yes, my common-sense thought is really the meaning of "milestone".) Three things seem to me to be wrong about considering this year's anniversaries as milestones, however. 
First, it is rather arbitrary that we like the "round" numbers of 10 and 20. It is an historical accident is that this many:

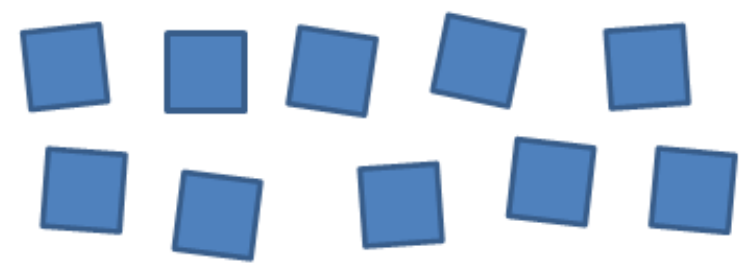

is even considered a "round" number. This many years is only round because we humans most often happen to have 5 - and not 4 or 6 - fingers on each of our two hands. If we only had 4 fingers as the most common number, this many years would be " $12{ }^{\prime \prime}$. How easily - and firmly - we seem to be attached to what is almost certainly an evolutionary accident, now embodied (or perhaps I should say "embalmed"?) as a social convention! If we were able to reset humanity's precursors back to an earlier evolutionary time, and let the situation play itself forward again, it is unlikely that we would end up with five fingers as the norm. (See Gould, quoted in Rosenberg, 1990, p. 1.) I believe that it is likewise true that many of our important "milestones" are merely accidental properties of complex systems.

Second, further reflection leads me to the awareness that it isn't the passing of a milestone - the completion of an arbitrary thing - that is important. It isn't really even the original event - in this case, Doll's publication - that is important as a milestone. In fact, I don't think that milestones are important. Instead, I am aware that these events are important to us as touchstones - things that we return to again and again to remind ourselves of who we are, or at least, of who we are as educational complexivists. Touchstones are not things we have completed, but rather part of our process of being and becoming. And, in a very real sense, I see these touchstones as like a strange attractor: Specifically, touchstones are those regions in phase space to which we keep passing through, but each time we return to them, we return different from the previous pass. (I have a small touchstone in my office that I glance over frequently. Given to me by a friend, it is etched with a picture of a kite and the words carpe diem.)

But touchstones are not millstones to which we are tied, keeping us in one place. Instead, touchstones are important in our lives - and in our academic lives - because they are reminders of connections, connections that are ongoing and organic, even as the connections remain the same. Our relationships are always changing, and touchstones can be reminders of both the change that occurs while simultaneously reminding us of some of the constants in our lives. (Whitehead, I am confident, would approve of this notion.) In this sense, Complicity is for me a touchstone. It has, for me, gone from an exciting new venue in which I could see new ideas to, now, something that I must take care of, and oversee production of, even though I still find new ideas in each issue. But the change is as much me as it is Complicity, and hence, I'm reminded that touchstones

1 This is read " 12 base 8 ". 
really act as mirrors: they show each of us our changes as much as the touchstones themselves change.

Complicity has changed in many ways over the 10 years. I believe that the overall quality of articles appearing in Complicity has improved since its founding. However, I believe this to be a reflection of the deepening understanding of complexity by researchers in the educational community rather than some quality that the journal possesses. For example, as satisfying as it would be for me to think that Complicity has been run by a series of editors, each better than the last, quite the contrary is probably true in my case. (After taking over as Editor-in-Chief, I re-read all the editorials that have appeared in Complicity since its founding. The major things I learned from that exercise are that I have a long way to go to become a better writer, and a long way to go to become a better editor.)

All of this brings me to my third thought about milestones. Milestones are entirely external. They belong to the path, and not to the journey. As such, they can easily be used as measuring devices, and also can contribute to "objective" comparisons. However, when used in such comparisons, milestones always seem to become millstones, either crushing the spirit of those who are so measured, or tied as a weight to prevent further progress, or broken into smaller pieces and thrown at the students as just plain old stones. It seems to me that the continual push towards higher-stakes testing (and more of it!) has replaced what could be touchstones with what are de facto millstones. Certainly, Dewey, Whitehead, Freire, and others would argue against these "objective" assessments of students if they were here. In their absence, I suppose it is we who must speak in their place.

To return to my starting thoughts, the people living in Ireland have long had to deal with stones, and seemingly have found a way to change stones from merely obstacles to growing food into useful materials for fences, shelter, and housing. Perhaps we can find analogous ways to deal with the stones of education.

\section{In this issue}

The five pieces in this issue - four research articles and one vignette - all deal with educational stones in one way or another.

Collins and Ting remind us that neither teachers nor students are stones. Instead, we are vulnerable, to the milestones by which we are measured and to the stones and arrows of our everyday and pedagogic lives. Teachers, therefore, must care for their students. And, while the temptation may be for us teachers to build a stone wall behind which we can hide and be protected, Collins and Ting suggest another path.

Koopmans considers how milestones are not sufficient to understand the journey, even if they do mark the path. His examination of the "gold standard" of educational research, randomized controlled trials (RCT), and all that accompanies the pursuit of RCT, shows that such methods, which perhaps sufficient for plain old stones, are quite inadequate for the study of complex systems. In doing this, Koopmans contributes to the 
body of literature that calls for new, or at least revised and expanded, methods of study of educational systems.

Not far from my house is a house with a well-made stone façade around the front door. But unlike the stone fences of Irish houses, the stones in this house were brought in during remodeling for the purpose of making the house look a certain way. No other house in the area has so many stones in it, and while the owners must like them, the stones are not really part of the neighborhood; instead, they are intruders. Trombly considers the importance of context in education, and sheds light on how the educational stones that are so integral to construction in one region can be so out of place in another.

Hussain, Connor and Mayo explore curriculum as an entity that is not set in stone. Instead, curriculum, like the students and teachers who participate in it, emerges from the dynamic interplay of many factors, some of which are the local context in which education occurs. And while their examination is of a particular curriculum in a particular context, their ideas certainly can serve as a touchstone to many others.

Lastly (at least by the well-ordered milestones of page numbers) is a vignette. In this vignette, Marsden parallels the research process to First Nations (of North America) hunting traditions: These undertakings both involve seeking, both involve what is sought, and both turn in unexpected ways. Both hunting and research involve touchstones, albeit very ethereal ones. And the vignette, for the willing reader, can provide a fascinating touchstone from which to read the other pieces of this issue.

\section{Postscript}

This is my first issue as Editor-in-Chief. The change was somewhat unexpected, but on behalf of the Complicity community, I want to thank Michel Alhadeff-Jones for his service as Editor-in-Chief and for his assistance during the transition. While his Editorship set a high standard for those of us who are and will be his successors, his graciousness in helping out even now makes the task of Editor-in-Chief much less imposing. I also want to thank the Editorial Team, the reviewers, and the authors who have made this transition as smooth as possible and who have put up with technical glitches as I learned the new system. It is my fervent hope that the review and editorial process moving forward will be more like a touchstone and less like throwing stones.

\section{References}

Rosenberg, B. (1990). Gould promotes the entity theory of evolution. The Tech, 110 (56). Friday, December 7, 1990. Retrieved from http://tech.mit.edu/V110/PDF/N56.pdf.

(C) Copyright 2014. The author, BERNARD P. RICCA, assigns to the University of Alberta and other educational and non-profit institutions a non-exclusive license to use this document for personal use and in courses of instruction provided that the article is used in full and this copyright statement is reproduced. The author also grants a non-exclusive license to the University of Alberta to publish this document in full on the World Wide Web, and for the document to be published on mirrors on the World Wide Web. Any other usage is prohibited without the express permission of the authors. 